Regular Article

\title{
Enhanced adsorption removal of antibiotics from aqueous solutions by modified alginate/graphene double network porous hydrogel
}

\author{
Yuan Zhuang a,d ${ }^{\text {, Fei } \mathrm{Yu}^{\mathrm{c}} \text {, Jie Ma }{ }^{\mathrm{a}, \mathrm{b}, *} \text {, Junhong Chen }}{ }^{\mathrm{a}, \mathrm{e}}$

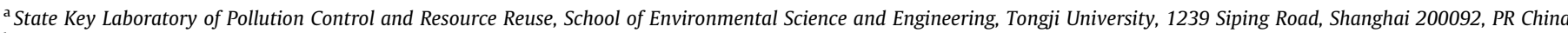 \\ ${ }^{\mathrm{b}}$ Research and Service Center for Environmental Protection Industry, Yancheng 224000, PR China \\ ' College of Chemistry and Environmental Engineering, Shanghai Institute of Technology, Shanghai 2001418, PR China \\ ${ }^{\mathrm{d}}$ Key Laboratory of Drinking Water Science and Technology, Research Center for Eco-Environmental Sciences, Chinese Academy of Sciences, Beijing, 100085, PR China \\ e Department of Mechanical Engineering, University of Wisconsin-Milwaukee, Milwaukee, WI 53211, USA
}

\section{G R A P H I C A L A B S T R A C T}

Modifications are made to obtain an excellent porous structure and more functional groups.

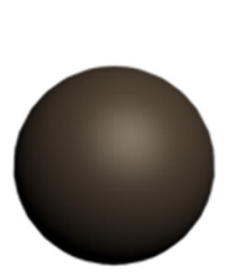

Double network hy drogel

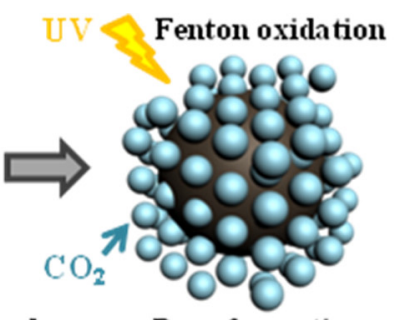

Pore formation

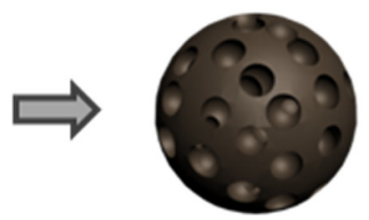

Por ous with abundant functional groups after modification

\section{A R T I C L E I N F O}

\section{Article history:}

Received 1 May 2017

Revised 23 June 2017

Accepted 9 July 2017

Available online 11 July 2017

\section{Keywords:}

Alginate

Graphene

Ciprofloxacin

Copper ion

Adsorption

\begin{abstract}
A B S T R A C T
Alginate/graphene double network hydrogel has recently been demonstrated as a promising adsorbent for water pollutants. To improve the adsorption capacity of the double network hydrogel, physical and chemical modifications are made to obtain an excellent porous structure and more functional groups. As-modified alginate/graphene double network hydrogel has a higher hydroxyl group content under a higher polyvinyl alcohol content and a higher carboxyl group content with a higher oxidation degree. Moreover, the $\mathrm{CO}_{2}$ produced by $\mathrm{CaCO}_{3}$ is used as pore formation agent avoiding the use of toxic organic matters. The modified alginate/graphene double network hydrogel shows a higher specific surface area, a larger mean pore diameter, and a higher pore volume with a higher initial $\mathrm{CaCO}_{3}$. In antibiotics adsorption, the mechanistic understanding shows that hydrogen bonds have greater influence on adsorption than carboxyl groups. The results reported here pave the way for the use of the alginate/graphene double network hydrogel for water treatment.
\end{abstract}

(c) 2017 Elsevier Inc. All rights reserved.

\footnotetext{
* Corresponding author at: State Key Laboratory of Pollution Control and Resource Reuse, School of Environmental Science and Engineering, Tongji University, 1239 Siping Road, Shanghai 200092, PR China.

E-mail addresses: jma@tongji.edu.cn (J. Ma), jhchen@uwm.edu (J. Chen).
}

\section{Introduction}

Water pollution is a serious problem around the world, because a large number of pollutants are discharged into the environment due to industrial, agricultural and other activities [1]. Knapp et al. 
[2] extracted DNA from long-term soil series in five different areas in the Netherlands from 1940 to 2008, and analyzed their existing antibiotics resistance genes. The results showed that all of the antibiotics resistance genes obviously enhanced. Among those antibiotics analyzed, resistance to tetracycline has increased by 15 times since the 1970s. Although the study of antibiotics has never stopped, acute and chronic effects of antibiotics-containing wastewater on the ecology and the potential threat have not yet been fully understood [3]. Therefore, it is very important to develop effective techniques for the removal of antibiotics in water.

At present, methods commonly used for antibiotics removal from water include biodegradation [4], electrochemical oxidation [5], advanced oxidation [6], photo catalytic [7], and adsorption method [8]. Among them, the adsorption method is widely used due to easy operation, adsorbents such as activated carbon [9], biological activated carbon [10], minerals (goethite [11,12], hematite [13], alumina [14], montmorillonite [15] and kaolinite [16]), carbon nanomaterials (carbon nanotubes [17], graphene [18]), and composite materials (magnetic graphite oxide [19], bovine serum protein/ $\mathrm{Fe}_{3} \mathrm{O}_{4}$ composite microspheres [20], $\mathrm{TiO}_{2} /$ high silica zeolite composites [21] and magnetic properties of $\mathrm{MnFe}_{2} \mathrm{O}_{4} /$ activated carbon composites [22], etc.) have shown promising adsorption properties. For easier separation of nanomaterial from water after adsorption, preparing nanomaterial hydrogel [23] and polymer composite hydrogel [24] is showed to be useful.

We have reported the synthesis of a novel alginate/reduced graphene oxide (RGO) double-network (GAD) hydrogel through a facile method, in which graphene was used to form one of the networks in the double network hydrogel for the first time. In that composite formation, the sodium alginate/graphene oxide (GO) mixture is dropped into $\mathrm{Ca}^{2+}$ solution to complete the alginate gelation, the obtained single network consists of 3D alginate networks and 2D GO. Then, after being treated by reduction, the 2D GO could form into 3D network, which interpenetrates but remains independent of the alginate network, and thus the double network gel is obtained. The GAD showed much better mechanical properties, stability and adsorption capacity than the alginate/RGO single network hydrogel (GAS) [25]. Moreover, through batch and column adsorption, GAD showed excellent removal properties for metals with maximum adsorption capacities of $169.5 \mathrm{mg} / \mathrm{g}$ for $\mathrm{Cu}^{2+}$ and $72.5 \mathrm{mg} / \mathrm{g}$ for $\mathrm{Cr}_{2} \mathrm{O}_{7}^{2-}$ [26]. However, the GAD's adsorption ability for organic matter has not been reported, and GAD also has the potential to be modified to obtain better adsorption capacity toward specific pollutants. Because pore structure and functional groups of an adsorbent have great influence on adsorption, physical and chemical modifications are used to modify GAD in this study to further improve the adsoprtion characteristics.

Freeze-drying, particulate leaching and gas-foaming methods (using supercritical fluids) have been used to produce porous polymers. With more defined and controlled pore structure, emulsion template methods are widely used in porous alginate preparation. Typically, organic matters especially oils are used as the templates in template methods, and then organic solvents which are usually toxic are used to remove the templates to form pores. However, the use of organic templates and organic solvents are not environmentally friendly. Partap et al. [27] used dense-phase $\mathrm{CO}_{2}$ droplets in an emulsion instead of isooctane to prepare 3D alginate hydrogels which exhibited an open, well-interconnected pore network with a narrow pore-size distribution. However, the reaction in this study needs a high-pressure reaction condition ( $5 \mathrm{MPa}$ ), and the production of dense-phase $\mathrm{CO}_{2}$ droplets is also of high cost. Sun et al. [28] reported a more facile way to prepare porous alginate hydrogel using $\mathrm{CO}_{2}$ to generate pores through the "internal setting" method. They located $\mathrm{CaCO}_{3}$ in alginate and chose $\mathrm{HCl}$ solution as the trigger. During the dropping step, $\mathrm{CaCl}_{2}$ and $\mathrm{CO}_{2}$ were generated at the same time. Thus gelation and pore formation happened simultaneously. However, we found that the simultaneous occurrence of gelation and pore formation easily lead to gel collapse and the alginate beads are shrunken as shown in Fig. S1.

In this study, to further improve the adsorption capacity of the double network hydrogel, alginate/graphene double network composite hydrogel beads were modified to have more pores and more functional groups. During modification, influences of polyvinyl alcohol (PVA) content and oxidation degree on functional groups and the influence of $\mathrm{CaCO}_{3}$ ratio on the pore structure were investigated. Moreover, the influence of modification on antibiotic adsorption properties was studied. The hydrogel showed to be more porous, have more functional groups and higher adsorption capacity after modification.

\section{Materials and methods}

\subsection{Materials}

All chemicals used in this study were purchased from Sinopharm Chemical Reagent Co., Ltd. (Shanghai, China) in analytical purity. All solutions were prepared using deionized water.

\subsection{Preparation of the samples}

GO was prepared using the modified Hummers' method [2931]. Briefly, graphite $(2.0 \mathrm{~g})$ and $\mathrm{NaNO}_{3}(1 \mathrm{~g})$ were placed in a $250 \mathrm{~mL}$ beaker. Then, $46 \mathrm{~mL}$ of sulfuric acid (98\%) was added with stirring in an ice bath. While maintaining the temperature below $283 \mathrm{~K}, 6 \mathrm{~g} \mathrm{KMnO}_{4}$ and $1 \mathrm{~g} \mathrm{NaNO}_{3}$ were slowly added to the suspension with vigorous stirring. After being stirred for $2 \mathrm{~h}$ in an ice bath, the mixture was stirred at $303 \mathrm{~K}$ for $30 \mathrm{~min}$. As the reaction proceeded, the color of the mixture gradually changed to brownish paste. Next, the paste was diluted with $92 \mathrm{~mL}$ ultra-pure water under vigorous agitation, heated to $368 \mathrm{~K}$ and then maintained for $30 \mathrm{~min}$. By then, the color of the suspension changed to bright yellow. When the suspension was cooled to room temperature, $10 \mathrm{ml} \mathrm{H}_{2} \mathrm{O}_{2}$ (30 wt\%) solution was added to the mixture to terminate the reaction, and the mixture was stirred for $2 \mathrm{~h}$ at room temperature. After centrifugation, the precipitate was repeatedly washed with $5 \% \mathrm{HCl}$ to remove residual metal ions, and then with deionized water to remove the sulfate ion. Finally, the precipitate (graphite oxide) was bath sonicated and dried under vacuum. The graphite oxide was dispersed in deionized water, and then sonicated in an ultrasonication bath for $12 \mathrm{~h}$ to obtain a GO dispersion.

To obtain double network hydrogel beads (GAD), $1 \mathrm{~g}$ sodium alginate and PVA (mass ratio of PVA to sodium alginate is 0,5 , 10, 20\%, named as PVA-0, PVA-5, PVA-10 and PVA-20) were dissolved in $100 \mathrm{~mL} 2 \mathrm{mg} / \mathrm{mL} \mathrm{GO}$ dispersion and stirred for $5 \mathrm{~h}$, and then $100 \mathrm{~mL}$ sodium alginate/PVA/GO dispersion was slowly dropped into $200 \mathrm{~mL} 10 \mathrm{mg} / \mathrm{mL} \mathrm{CaCl}_{2}$ solution using a peristaltic pump accompanied by magnetic stirring to obtain the alginate/ GO single network beads (GAS). To obtain double-network beads, the single network beads were placed into $2 \mathrm{mg} / \mathrm{mL}$ ascorbic acid solution (which is a reductant for GO) and heated in a water bath of $85^{\circ} \mathrm{C}$ for $12 \mathrm{~h}$.

To obtain porous double network hydrogel beads (PAG), $1 \mathrm{~g}$ sodium alginate, $200 \mathrm{mg}$ PVA and $\mathrm{CaCO}_{3}(10,100$ and $1000 \mathrm{mg}$ respectively) were dissolved in $100 \mathrm{~mL} 2 \mathrm{mg} / \mathrm{mL}$ GO solution and stirred for $5 \mathrm{~h}$, and then $100 \mathrm{~mL}$ sodium alginate/PVA/GO solution was slowly dropped into $200 \mathrm{~mL} 10 \mathrm{mg} / \mathrm{mL} \mathrm{CaCl}_{2}$ solution using a peristaltic pump accompanied by magnetic stirring to obtain the alginate/GO single network beads. To obtain double-network beads, the single network beads were placed into $2 \mathrm{mg} / \mathrm{mL}$ ascorbic 
acid solution (which is a reductant for $\mathrm{GO}$ ) and heated in a water bath of $85^{\circ} \mathrm{C}$ for $12 \mathrm{~h}$. Then the double network beads were put into $200 \mathrm{~mL} 30 \% \mathrm{HCl}$ solution to produce pores.

To obtain oxidized PAG, $1 \mathrm{~g}$ sodium alginate, $0.2 \mathrm{~g}$ PVA and $1 \mathrm{~g}$ $\mathrm{CaCO}_{3}$ were dissolved into $100 \mathrm{~mL} 2 \mathrm{mg} / \mathrm{mL}$ GO dispersionand stirred for $5 \mathrm{~h}$, and then $100 \mathrm{~mL}$ sodium alginate/PVA/GO dispersion was slowly dropped into $200 \mathrm{~mL} 10 \mathrm{mg} / \mathrm{ml} \mathrm{CaCl}_{2}$ solution using a peristaltic pump accompanied by magnetic stirring to obtain the alginate/GO single network beads. To obtain double-network beads, the single network beads were placed into $2 \mathrm{mg} / \mathrm{mL}$ ascorbic acid solution (which is a reductant for GO) and heated in a water bath of $85^{\circ} \mathrm{C}$ for $12 \mathrm{~h}$. Then the double network beads were put into $200 \mathrm{~mL} \mathrm{30 \%} \mathrm{HCl}$ solution. The obtained beads were put into $100 \mathrm{~mL} 1 \% \mathrm{FeCl}_{3}$ solution, and then $100 \mathrm{ml} \mathrm{H}_{2} \mathrm{O}_{2}$ solution (1, 2 and 5 wt\%, named as $\mathrm{H}_{2} \mathrm{O}_{2}-1, \mathrm{H}_{2} \mathrm{O}_{2}-2$, and $\mathrm{H}_{2} \mathrm{O}_{2}-5$ ) was dropped into the $\mathrm{FeCl}_{3}$ solution under $\mathrm{UV}$ and magnetic stirring.

\subsection{Characterization methods}

A field-emission SEM (Hitachi, S-4800) was used to investigate the surface morphologies of GAS and GAD. The specific surface area, pore volume (PV) and pore size distribution were tested by nitrogen adsorption/desorption at $77.4 \mathrm{~K}$ using an Accelerated Surface Area and Porosimetry system (Micromeritics, ASAP 2020), and all the beads were degassed at $373 \mathrm{~K}$ for $8 \mathrm{~h}$ before the measurements. The surface functional groups were observed by Fourier transform infrared spectroscopy (FTIR, NEXUS, 670). The ciprofloxacin concentrations in adsorption studies were measured by an ultraviolet spectrophotometer (Tianmei UV-2310(II)) at $270 \mathrm{~nm}$. ICP-OES tested the $\mathrm{Cu}^{2+}$ concentrations in solutions, inductively coupled plasma mass spectrometry (ICP-MS) Agilent 7700 (Agilent, USA) and atomic fluorescence spectrometry (AFS) FP6-A (PERSEE, China).The hydroxyl group and carboxyl group contents in the sample were tested by Boehm method [32]. Chemical oxygen demand (COD) is one of the most important water quality parameters for organic pollutants, and it can be used to determine the relative content of organic matter in the water. In this experiment, COD test was operated according to the GB11914-89 standard method, and the concentration was calculated based on the absorbance under $440 \mathrm{~nm}$ using an ultraviolet spectrophotometer (Tianmei UV-2310(II)). TOC and TN were measured by the TOC/TN instrument (TOC-VCSH, Japan).

\subsection{Batch adsorption studies}

The kinetic studies were operated under initial concentration $300 \mathrm{mg} / \mathrm{mL}$ in a thermostatic shaker in $\mathrm{pH} 8$ at $298 \mathrm{~K}$ and $150 \mathrm{rpm}$ under solid to the liquid ratio $1 \mathrm{mg} / \mathrm{mL}$.
The adsorption isotherms were studied in a thermostatic shaker in $\mathrm{pH} 8$ at $298 \mathrm{~K}$ and $150 \mathrm{rpm}$ for $24 \mathrm{~h}$ under solid to the liquid ratio $1 \mathrm{mg} / \mathrm{mL}$. The initial concentrations of the antibiotics are 50,100, $200,300,400$ and $500 \mathrm{mg} / \mathrm{mL}$ respectively.

All the samples were operated in 3 duplicates with presented data in equal $\left(\mathrm{R}^{2}>\mathrm{t} 0.98\right)$. After adsorption, the samples were separated by a $0.45 \mu \mathrm{m}$ membrane. The residual concentrations in the solution were determined by an ultraviolet spectrophotometer (Tianmei UV-2310(II)) at $360 \mathrm{~nm}$ for tetracycline and $270 \mathrm{~nm}$ for ciprofloxacin. Eq. (1) was used to calculate the adsorption capacity (mg/g) [33].

$q_{t}=\left(C_{0}-C_{t}\right) \times \frac{V}{m}$

where $C_{0}$ and $C_{t}$ are the initial concentration and the concentration after a period $\mathrm{t}(\mathrm{mg} / \mathrm{L})$; $\mathrm{V}$ is the initial solution volume $(\mathrm{L})$, and $\mathrm{m}$ is the adsorbent dosage $(\mathrm{g})$.

The actual sewage is taken from the first precipitation tank of the Quyang sewage treatment plant (Shanghai, China) in March 2016 with COD $180 \mathrm{mg} / \mathrm{L}, \mathrm{B} / \mathrm{C} \quad 0.4$, TOC $15.59 \mathrm{mg} / \mathrm{L}$ and TN $25.13 \mathrm{mg} / \mathrm{L}$. 5-50 $\mathrm{mg}$ hydrogel beads were put into $20 \mathrm{~mL}$ sewage. After the adsorption equilibrium was reached, the TN, COD and TOC before and after the reaction were tested. Each group was set up in the blank control group and three parallel samples, and the final equilibrium concentration was taken as the average of the three experiments.

\section{Results and discussion}

\subsection{The structure of $G A D$}

Fig. 1a is a photograph of GAD beads, from which can be seen that the beads have a spherical shape with a smooth surface. The relatively uniform size of the bead is about $0.5 \mathrm{~cm}$. SEM image of GAD is shown in Fig. $1 \mathrm{~b}$, and it can be seen that there are petallike structures. As is known that graphene is of a sheet structure, the petal-like structures may be generated from the selfassembly process of graphene sheets.

\subsection{The adsorption properties of GAD}

\subsubsection{Adsorption kinetics}

Kinetic study of antibiotic adsorption on GAS and GAD is shown in Fig. 2. Since the adsorption process changes with time as shown in Fig. 2a, the adsorption of GAS and GAD both reached equilibrium within $24 \mathrm{~h}$. However, the GAD adsorption rate is higher than that of GAS, which is due to the larger specific surface area of GAD. The adsorption process is fitted by pseudo first order, pseudo second order and intra-particle
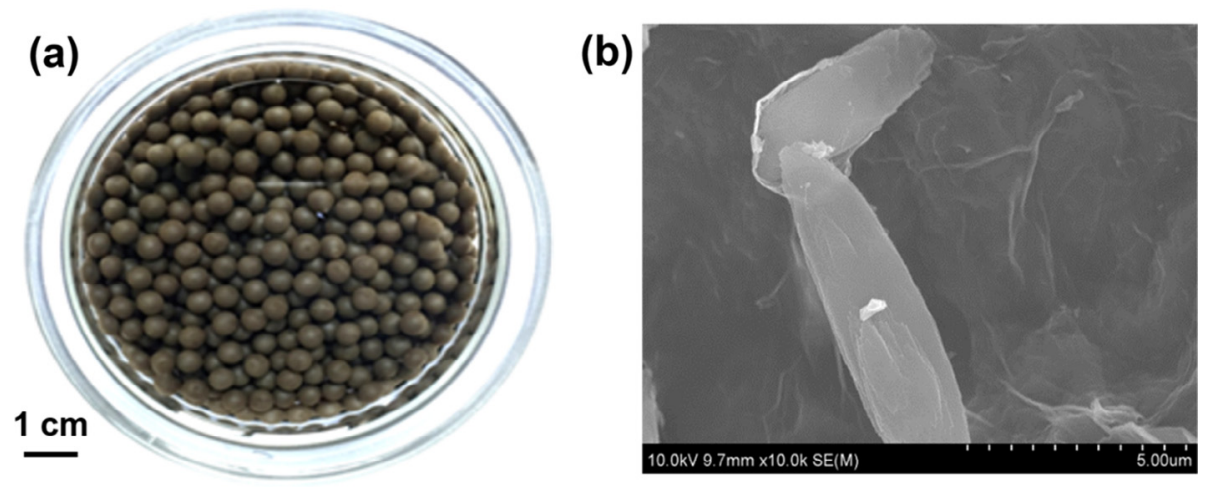

Fig. 1. Photograph (a) and SEM (b) of GAD. 

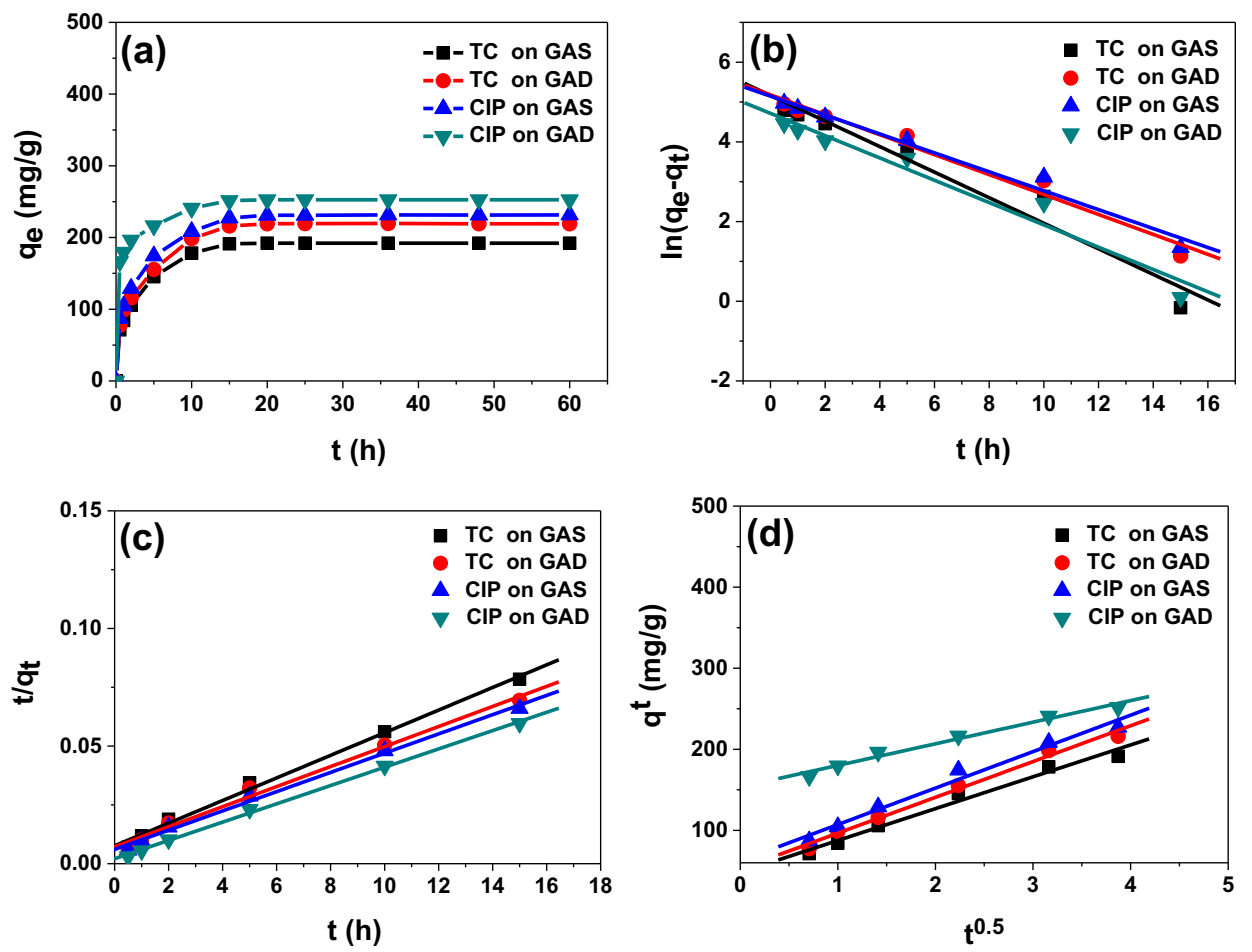

Fig. 2. Kinetic curves (a), pseudo-first order model (b), pseudo-second order model (c) and intra-particle diffusion model (d) of antibiotic adsorption on GAS and GAD.

Table 1

Kinetic parameters of pseudo first- and second-order adsorption kinetic models and intra-particle diffusion model.

\begin{tabular}{|c|c|c|c|c|c|}
\hline \multirow[t]{2}{*}{ Kinetic model } & \multirow[t]{2}{*}{ Parameters } & \multicolumn{2}{|c|}{ Tetracycline } & \multicolumn{2}{|c|}{ Ciprofloxacin } \\
\hline & & GAS & GAD & GAS & GAD \\
\hline Pseudo-first order & $\begin{array}{l}\mathrm{q}_{\mathrm{e}}(\mathrm{mg} / \mathrm{g}) \\
k_{1}(1 / \mathrm{min}) \\
R^{2}\end{array}$ & $\begin{array}{l}174.16 \\
0.7369 \\
0.9400\end{array}$ & $\begin{array}{l}177.68 \\
0.5758 \\
0.9666\end{array}$ & $\begin{array}{l}172.43 \\
0.5297 \\
0.9752\end{array}$ & $\begin{array}{l}111.05 \\
0.6448 \\
0.9457\end{array}$ \\
\hline Pseudo-second order & $\begin{array}{l}q_{e}(\mathrm{mg} / \mathrm{g}) \\
k_{2}(\mathrm{~g} / \mathrm{mg} \cdot \mathrm{min}) \\
R^{2}\end{array}$ & $\begin{array}{l}208.33 \\
0.0048 \\
0.9931\end{array}$ & $\begin{array}{l}238.10 \\
0.0042 \\
0.9881\end{array}$ & $\begin{array}{l}250.00 \\
0.0040 \\
0.9933\end{array}$ & $\begin{array}{l}263.16 \\
0.0038 \\
0.9972\end{array}$ \\
\hline Intra-particle diffusion & $\begin{array}{l}\mathrm{k}_{\mathrm{id}}\left(\mathrm{mg} / \mathrm{g} \cdot \mathrm{min}^{0.5}\right) \\
\mathrm{C}(\mathrm{mg} / \mathrm{g}) \\
R^{2}\end{array}$ & $\begin{array}{l}39.29 \\
48.20 \\
0.9760\end{array}$ & $\begin{array}{l}44.13 \\
52.45 \\
0.9769\end{array}$ & $\begin{array}{l}44.98 \\
62.17 \\
0.9757\end{array}$ & $\begin{array}{l}26.64 \\
153.49 \\
0.9906\end{array}$ \\
\hline
\end{tabular}

diffusion models as shown in Fig. 2 2b-d, and the fitting parameters are shown in Table 1 . The fitting coefficient $R^{2}$ of pseudo second order is higher than that of the other two models, which indicates that the pseudo second order could reflect the whole process of adsorption better; The intra-particle diffusion model could be used to study the adsorption stage and the adsorption mechanism. Usually intra-particle diffusion model consists of three stages: in the first stage, outer surface adsorption or boundary layer diffusion; the second stage is gradual adsorption process, which could also be called intraparticle diffusion process; If the $\mathrm{q}_{\mathrm{t}}$ hasa linear relationship with $\mathrm{t}^{0.5}$ and the straight line is through the origin, the adsorption process is a speedcontrol process; in the third stage, final part of the adsorption process becomes the final balance due to the low molecular concentration of antibiotic solution and the lack of adsorption sites on the surface of the adsorbent [34]. If the $t^{0.5}$ is plotted linearly with $\mathrm{q}_{\mathrm{t}}$ but the straight line does not pass the origin, the adsorption process is not a speed-control process [35]. In summary, pseudo second order is the most suitable model to describe the adsorption process here, and the adsorption process is a speed-control process [36,37].

\subsubsection{Adsorption isotherm}

Adsorption isotherm is an important way to study the adsorption process. By fitting the adsorption data with different adsorption isotherm models, it can be used to study the distribution of adsorbed molecules on the solid-liquid interface during the adsorption process [38]. Four types of adsorption isotherms are used to fit the adsorption data as shown in Fig. 3, and the fitting parameters are shown in Table 2. It can be seen that all the adsorption processes in this study are well fitted by the Langmuir adsorption isotherm as shown in Fig. 3a, indicating they are monolayer adsorption and materials have good uniform surfaces. The maximum adsorption capacities of tetracycline and ciprofloxacin on GAD is $290.70 \mathrm{mg} / \mathrm{g}$ and $344.83 \mathrm{mg} / \mathrm{g}$, which are higher than those of GAS, alginate, graphene in this study and also many other adsorbents as shown in Tables 2 and 3. The Freundlich isotherm is an empirical equation which could be used to describe heterogeneous adsorption process. Freundlich adsorption isotherms are used to fit the adsorption process as shown in Fig. $3 \mathrm{~b}$, and the good fitting results indicate the material surfaces are of different adsorption sites with different adsorption energies. It can be noticed that the adsorption isotherms are fitted better by the Langmuir model 

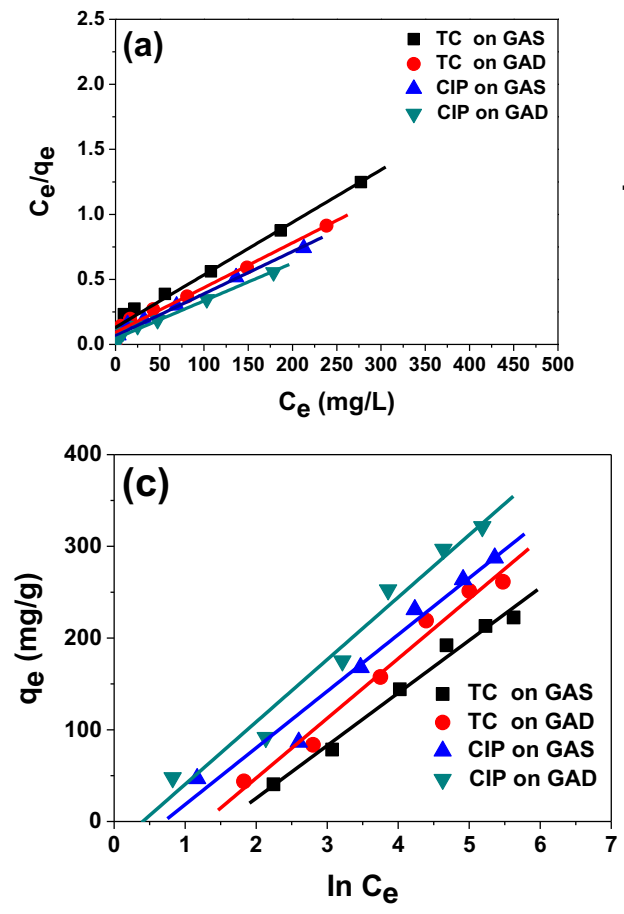
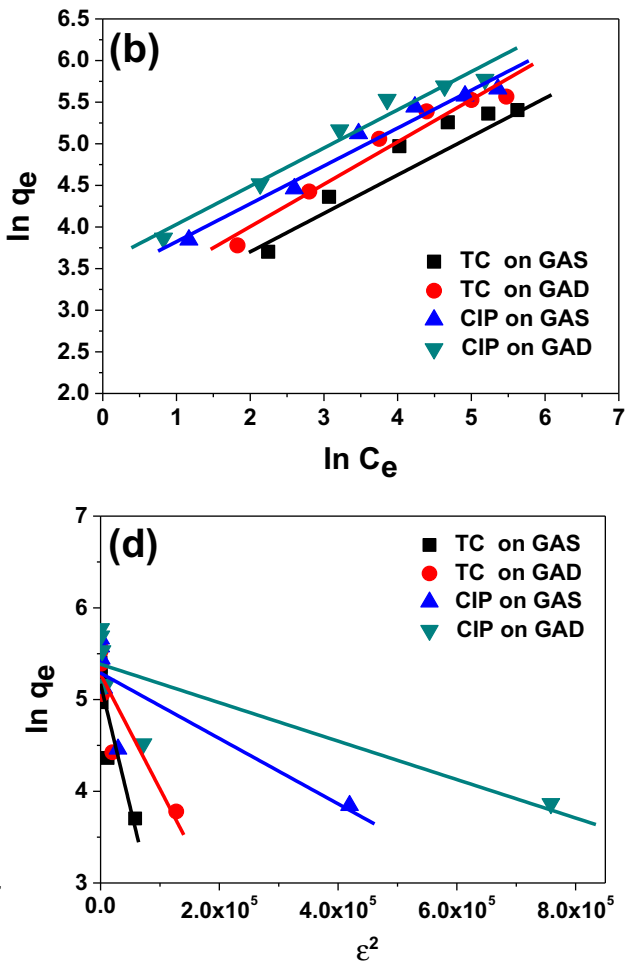

Fig. 3. Langmuir (a), Freundlich (b), Temkin (c) and D-R (d) isotherm models for antibiotic adsorption on GAS and GAD.

Table 2

Langmuir, Freundlich, Temkin, and D-R isotherm parameters of antibiotic adsorption on GAD.

\begin{tabular}{|c|c|c|c|c|c|}
\hline \multirow[t]{2}{*}{ Isotherm model } & \multirow[t]{2}{*}{ Parameters } & \multicolumn{2}{|l|}{ Tetracycline } & \multicolumn{2}{|l|}{ Ciprofloxacin } \\
\hline & & GAS & GAD & GAS & GAD \\
\hline Langmuir & $\begin{array}{l}\mathrm{q}_{\mathrm{m}}(\mathrm{mg} / \mathrm{g}) \\
K_{L}(\mathrm{~L} / \mathrm{mg}) \\
R_{L} \\
R^{2}\end{array}$ & $\begin{array}{l}247.52 \\
0.0305 \\
0.0985 \\
0.9719\end{array}$ & $\begin{array}{l}290.70 \\
0.0374 \\
0.0818 \\
0.9731\end{array}$ & $\begin{array}{l}308.64 \\
0.0498 \\
0.0627 \\
0.9787\end{array}$ & $\begin{array}{l}344.83 \\
0.0644 \\
0.0492 \\
0.9826\end{array}$ \\
\hline Freundlich & $\begin{array}{l}\mathrm{K}_{\mathrm{F}}((\mathrm{mg} / \mathrm{g})(\mathrm{L} / \mathrm{mg}) 1 / \mathrm{n}) \\
n \\
R^{2}\end{array}$ & $\begin{array}{l}15.47 \\
1.9698 \\
0.9305\end{array}$ & $\begin{array}{l}19.83 \\
1.9661 \\
0.9429\end{array}$ & $\begin{array}{l}29.05 \\
2.1982 \\
0.9585\end{array}$ & $\begin{array}{l}36.30 \\
1.5825 \\
0.9606\end{array}$ \\
\hline Temkin & $\begin{array}{l}\mathrm{K}_{\mathrm{T}}(\mathrm{L} / \mathrm{mol}) \\
B_{T} \\
R^{2}\end{array}$ & $\begin{array}{l}0.2109 \\
57.34 \\
0.9837\end{array}$ & $\begin{array}{l}0.2797 \\
65.15 \\
0.9755\end{array}$ & $\begin{array}{l}0.4962 \\
61.74 \\
0.9621\end{array}$ & $\begin{array}{l}0.6685 \\
67.96 \\
0.9575\end{array}$ \\
\hline D-R & $\begin{array}{l}\mathrm{q}_{\mathrm{m}}(\mathrm{mg} / \mathrm{g}) \\
\beta\left(\mathrm{mol}^{2} / \mathrm{kJ}{ }^{2}\right) \\
\mathrm{E}(\mathrm{kJ} / \mathrm{mol}) \\
R^{2}\end{array}$ & $\begin{array}{l}175.91 \\
2.19 \times 10^{-5} \\
661.85 \\
0.7953\end{array}$ & $\begin{array}{l}194.42 \\
1.24 \times 10^{-5} \\
498.00 \\
0.7233\end{array}$ & $\begin{array}{l}198.34 \\
3.56 \times 10^{-6} \\
2668.33 \\
0.6186\end{array}$ & $\begin{array}{l}217.02 \\
2.09 \times 10^{-6} \\
2044.50 \\
0.6368\end{array}$ \\
\hline
\end{tabular}

Table 3

Maximum adsorption capacity of other materials for tetracycline (based on Langmuir model).

\begin{tabular}{lll}
\hline Adsorbent & $\mathrm{q}_{\mathrm{m}}(\mathrm{mg} / \mathrm{g})$ & Reference \\
\hline GO functionalized magnetic particles & 39.1 & {$[42]$} \\
Macroporous polystyrene resins & 98.04 & {$[43]$} \\
Modified bio-char & 17.0 & {$[44]$} \\
Activated carbon & 475.48 & {$[45]$} \\
GAD & 290.70 & This study \\
GAS & 247.52 & This study \\
\hline
\end{tabular}

than by the Freundlich model, suggesting that antibiotic adsorption onto GAS and GAD is monolayer coverage. By fitting the Temkin model, as shown in Fig. 3c, the good fitting results indicate the binding force would decrease linearly with increasing antibiotic molecule covering layers, thus the adsorption is dominated by the uniformly distributed binding force [39]; D-R model could be used to calculate the average adsorption energy (E) and also to study the physical and chemical adsorption [40]. When one-mole ions are transferred, the E value in $1-8 \mathrm{~kJ} / \mathrm{mol}$ corresponds to physical adsorption; the $\mathrm{E}$ in $8-16 \mathrm{~kJ} / \mathrm{mol}$ indicates that the adsorption process is mainly ion exchange; and the $\mathrm{E}$ in $20-40 \mathrm{~kJ} / \mathrm{mol}$ corresponds to chemical adsorption [41].

\subsection{The adsorption properties of modified alginate/graphene double network hydrogel}

\subsubsection{Effect of graphene content}

The effect of GO concentration on antibiotic adsorption is shown in Fig. 4, from which can be seen that the adsorption capacity increases with increasing GO content. On one hand, graphene has a higher specific surface area and more abundant pore 


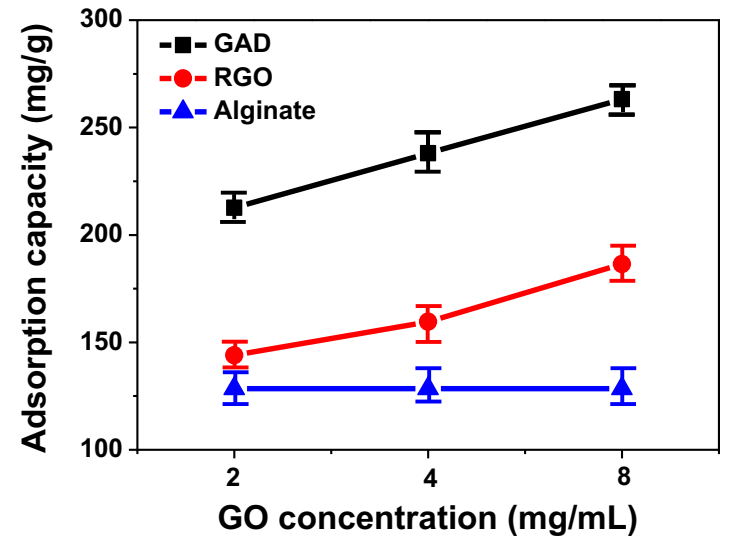

Fig. 4. Influence of GO concentration on ciprofloxacin adsorption on GAD (initial concentration $300 \mathrm{mg} / \mathrm{ml}, 298 \mathrm{~K}$, solid to liquid ratio $1 \mathrm{mg} / \mathrm{ml}, \mathrm{pH} 8$ ).

structure than alginate; on the other hand, when graphene content is higher, the $\pi-\pi$ bond between the material and antibiotic is stronger. However, as the cost of graphene is high, $2 \mathrm{mg} / \mathrm{ml}$ is selected as the GO concentration for the following adsorption experiment.

\subsubsection{Effect of $\mathrm{CaCO}_{3}$}

To further investigate the influence of pore formation process on the hydrogel structure, specific area and pore information of PAG under different initial $\mathrm{CaCO}_{3}$ content were tested. Fig. $5 \mathrm{a}$ is the photograph of PAG beads; there are lots of bubbles appearing on the surface of the hydrogel beads. It is because that the $\mathrm{CaCO}_{3}$ in the hydrogel reacts with $\mathrm{HCl}$ to create $\mathrm{CO}_{2}$, and the $\mathrm{CO}_{2}$ acts as pore creating agents to make the hydrogel porous. Moreover, the other product $\mathrm{CaCl}_{2}$ from the reaction of $\mathrm{CaCO}_{3}$ with $\mathrm{HCl}$ is the crosslinking agent of alginate. Thus the process does not bring other impurities into the sample. SEM image of PAG is shown in Fig. 5b. It can be seen the PAG has a much more porous structure than CAG (Fig. 1b), which proved that the $\mathrm{CO}_{2}$ is effective for the pore formation in this composite hydrogel.

As shown in Fig. S2 and Table S1, GAD have large specific area and larger pore size than GAS. It can be seen from $\mathrm{N}_{2}$ adsorption and desorption curves and pore distributions as shown in Fig. 6 and Table 4 that the PAG sample has a higher specific surface area, a larger average pore diameter, and a bigger pore volume with the increase of $\mathrm{CaCO}_{3}$ content. Thus, the double network hydrogels have large specific area and larger pore size than the single network hydrogels. Moreover, after the pore formation process, that the double network hydrogel could become more porous. The structure would be benefit for the application in adsorption.
Ciprofloxacin adsorption on PAG under different initial $\mathrm{CaCO}_{3}$ content is shown Fig. 6b. It can be seen that PAG has higher adsorption capacity toward ciprofloxacin with the increase of $\mathrm{CaCO}_{3}$ content. It is because the PAG has a more porous structure with larger specific surface area under a higher $\mathrm{CaCO}_{3}$ content, which is a benefit for its contact with the pollutants.

\subsubsection{Effect of PVA}

Beside pore structure, functional groups also have great influence on adsorption. Polyvinyl alcohol (PVA) is a biopolymer that is commonly used to remove heavy metals from wastewater because it is nontoxic, and cheap. However, PVA has a tendency to agglomerate and thus it is usually combined with alginate for use [46]. As PVA contains abundant $-\mathrm{OH}$, the addition of PVA into the double network may be effective for the improvement of adsorption capacity. As hydroxyl group has great influence on antibiotic adsorption, PVA is used to modify the double network as it contains abundant hydroxyl groups. FTIR of GO and alginate are shown in Fig. S3. The FTIR of PAG under different PVA content is shown in Fig. 7a to investigate the influence of PVA on functional groups. It can be seen that all the samples have obvious peaks around $1407 \mathrm{~cm}^{-1}$, which reflects the abundant content of hydroxyl groups in the sample [47]. With the increase of PVA content, the broad peaks around $1407 \mathrm{~cm}^{-1}$ and $3,200-3700 \mathrm{~cm}^{-1}$ in all the samples became stronger, which reflected the enhancement of hydroxyl groups [48]. Moreover, there were no new peaks appearing after the PVA addition, which indicated that there are no covalent bonds between PVA and the double network. Thus they may bond by hydrogen bonds. Under a higher oxidation degree, peaks around $1616 \mathrm{~cm}^{-1}$ became stronger, indicating the formation of carboxyl groups during the oxidation process.

The hydroxyl and carboxyl groups content in PAG and ciprofloxacin adsorption capacity under different PVA content is shown in Fig. 7b. With the increase of PVA content, the hydroxyl content of PAG significantly increased, but the carboxyl content gradually decreased, which was due to the PVA containing hydroxyl group contained no carboxyl group, and the PVA addition would lead to decrease in the carboxyl group content.

\subsubsection{Effect of oxidation}

Beside hydroxyl groups, carboxyl groups also have great influence on antibiotic adsorption. PAG is put into $\mathrm{H}_{2} \mathrm{O}_{2}$ and $\mathrm{FeCl}_{3}$ solution to be oxidized. FTIR spectrum of the hydrogel under different $\mathrm{H}_{2} \mathrm{O}_{2}$ content is shown in Fig.8a. The hydroxyl and carboxyl groups content in PAG and ciprofloxacin adsorption capacity under different $\mathrm{H}_{2} \mathrm{O}_{2}$ content is shown in Fig.8b. Carboxyl content increased significantly with increasing the content of $\mathrm{H}_{2} \mathrm{O}_{2}$, but hydroxyl content decreased gradually. This is due to the hydroxyl groups being oxidized to carboxyl oxidation in the Fenton reaction,

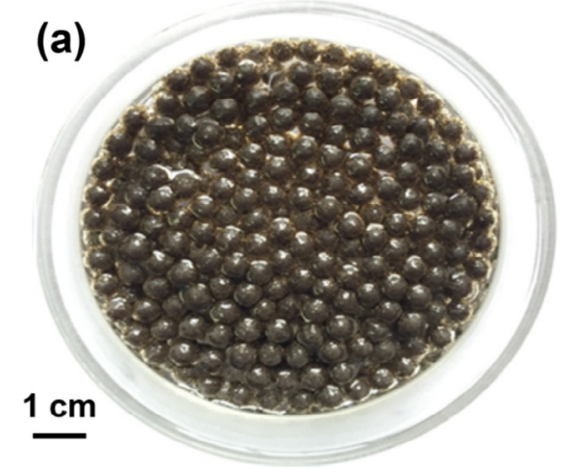

(b)

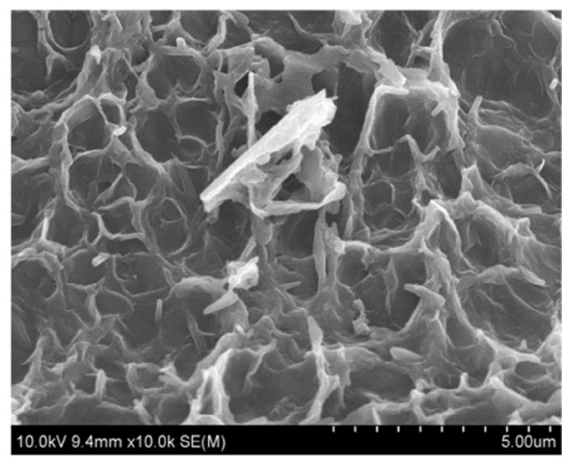

Fig. 5. Photograph (a) and SEM image, (b) of PAG. 

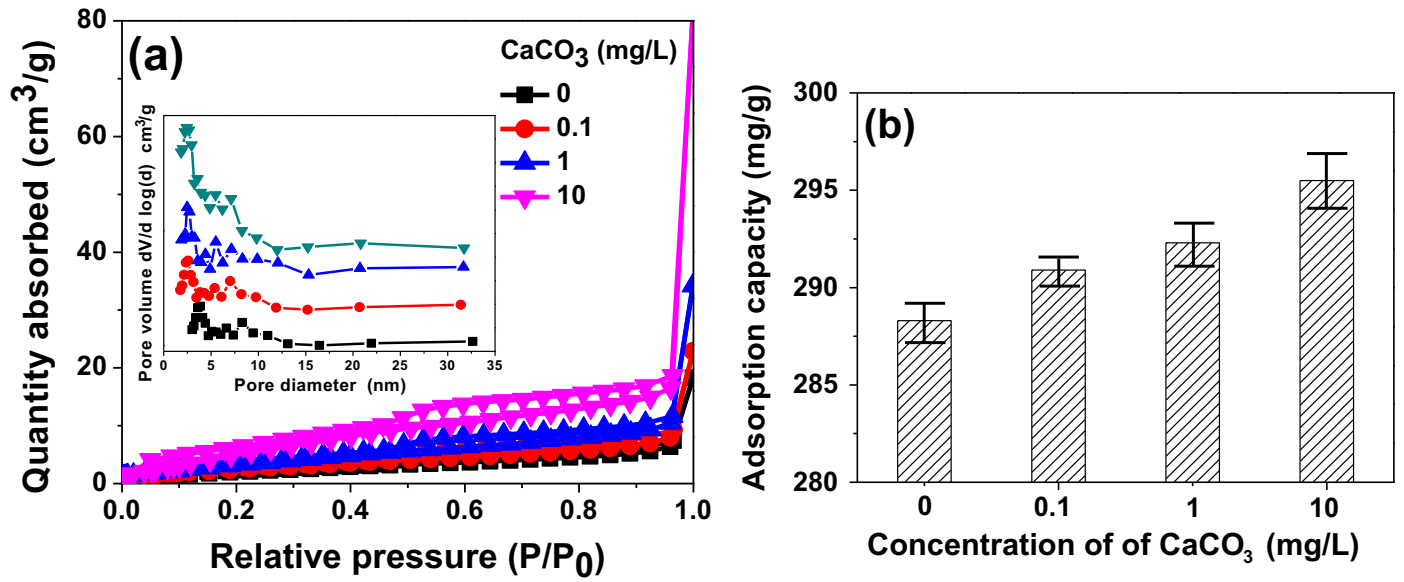

Fig. 6. (a) $\mathrm{N}_{2}$ adsorption and desorption curves and pore distributions, (b) ciprofloxacin adsorption capacity of PAG under different initial CaCO $\mathrm{C}_{3}$ concentrations.

Table 4

Specific surface area and pore information of PAG under different initial $\mathrm{CaCO}_{3}$ content.

\begin{tabular}{llll}
\hline Characteristics & $\begin{array}{l}\text { Specific surface } \\
\text { area }\left(\mathrm{m}^{2} / \mathrm{g}\right)\end{array}$ & $\begin{array}{l}\text { Average pore } \\
\text { diameter }(\mathrm{nm})\end{array}$ & $\begin{array}{l}\text { Pore volume } \\
\left(\mathrm{cm}^{3} / \mathrm{g}\right)\end{array}$ \\
\hline $\mathrm{CaCO}_{3}-0$ & 8.25 & 9.25 & 0.028 \\
$\mathrm{CaCO}_{3}-0.1$ & 10.17 & 10.66 & 0.035 \\
$\mathrm{CaCO}_{3}-1$ & 14.08 & 11.91 & 0.055 \\
$\mathrm{CaCO}_{3}-10$ & 26.21 & 15.39 & 0.125 \\
\hline
\end{tabular}

leading to carboxyl content increases at the same time, decreased hydroxyl content. The adsorption capacity of ciprofloxacin decreased with the increase of oxidation degree. In the ciprofloxacin adsorption on PAG, the hydroxyl groups in PAG could form hydrogen bonds with the hydroxyl and amino groups in ciprofloxacin, and the carboxyl groups in PAG could form hydrogen bonds with the hydroxyl and amino groups in ciprofloxacin. As PAG has a higher adsorption capacity to ciprofloxacin under higher hydroxyl group content, indicating hydrogen bond has higher contribution than carboxyl group in the ciprofloxacin adsorption.
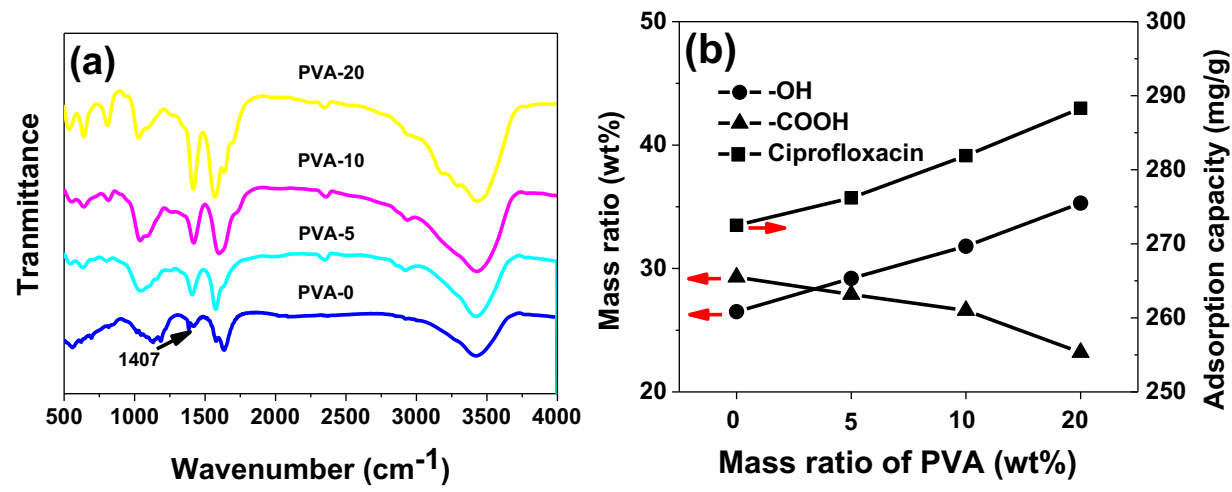

Fig. 7. (a) FTIR spectrum and, (b) hydroxyl group, carboxyl group contents and ciprofloxacin adsorption capacity of PAG under different PVA content.
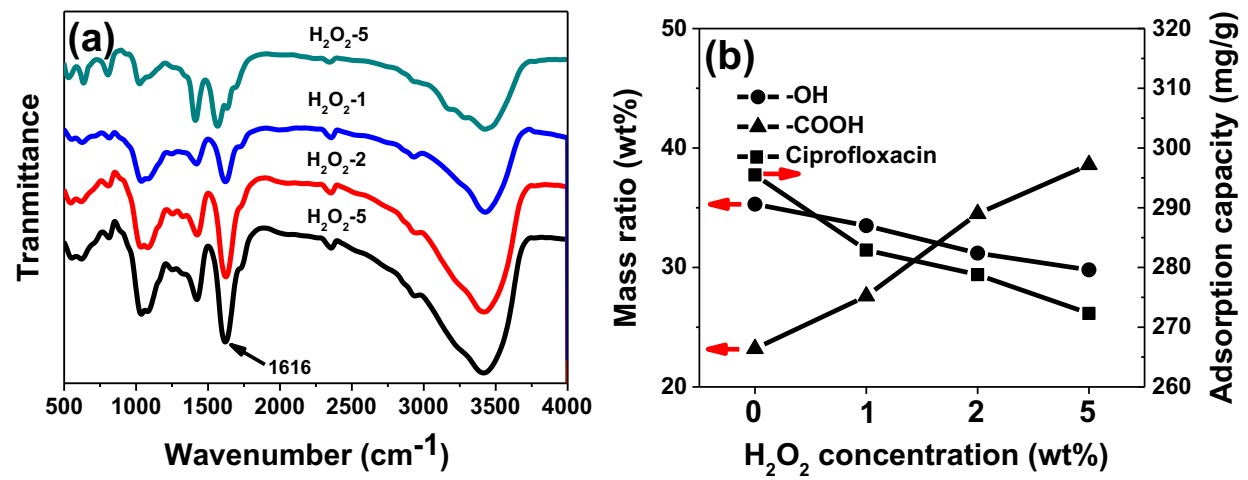

Fig. 8. (a) FTIR spectrum and, (b) hydroxyl group, carboxyl group contents and ciprofloxacin adsorption capacity of PAG under different $\mathrm{H}_{2} \mathrm{O}_{2}$ oxidation content. 

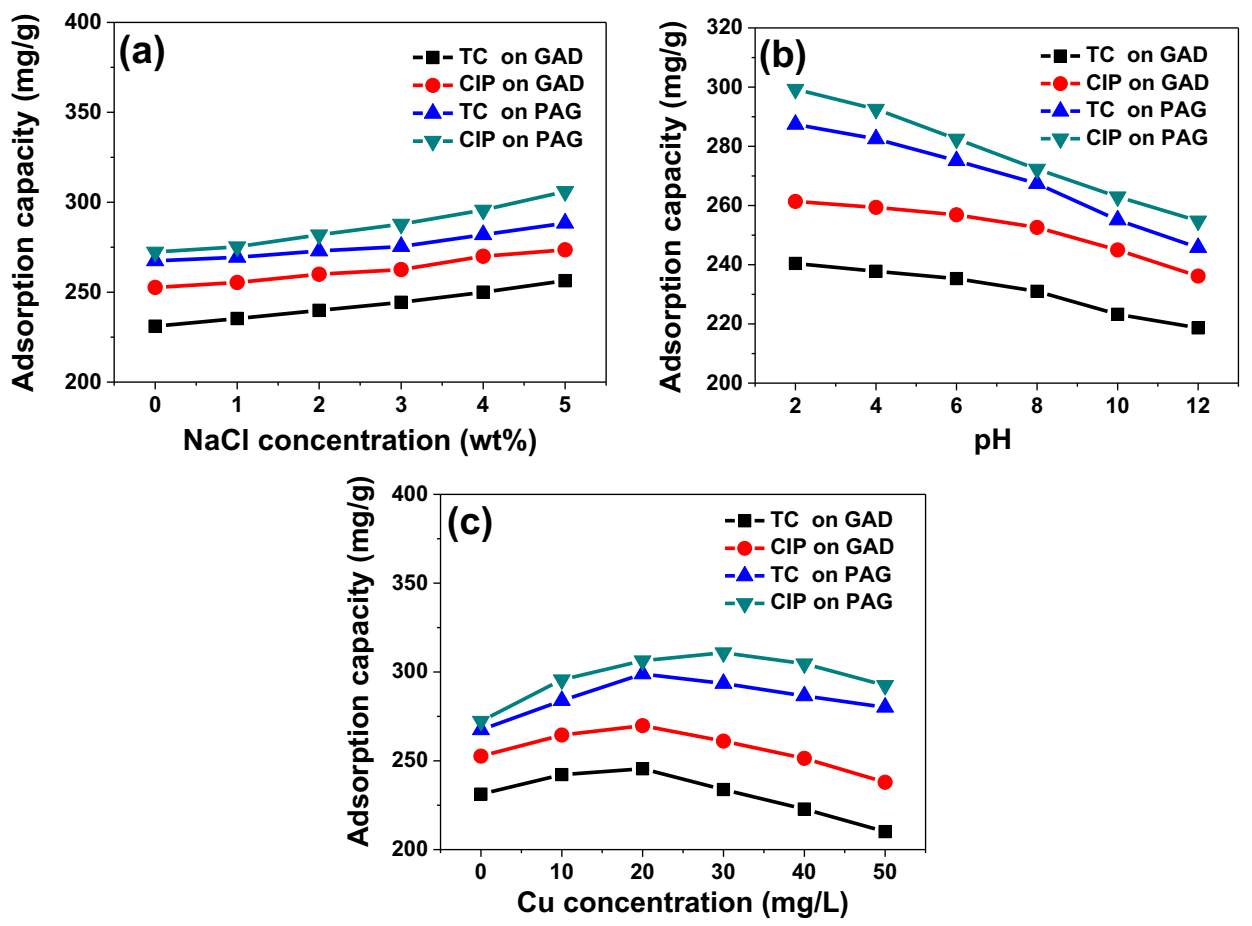

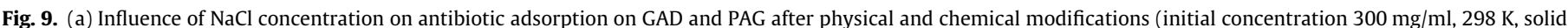

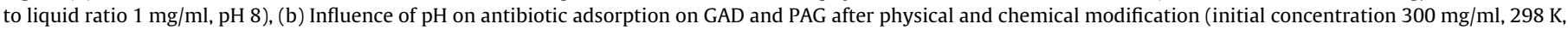

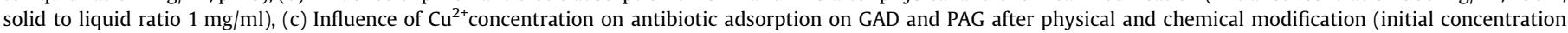
$300 \mathrm{mg} / \mathrm{ml}, 298 \mathrm{~K}$, solid to liquid ratio $1 \mathrm{mg} / \mathrm{ml}, \mathrm{pH} 8$ ).
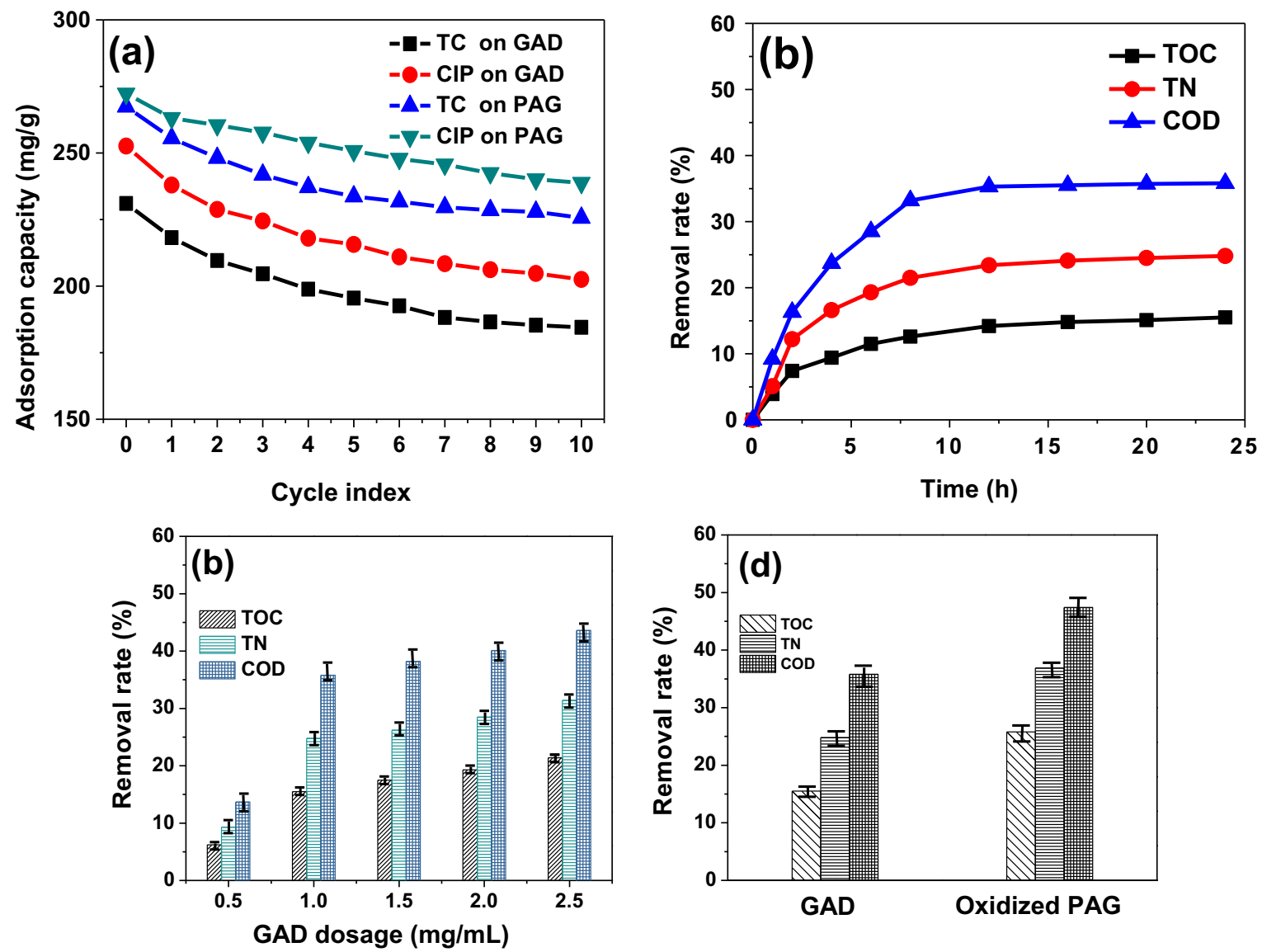

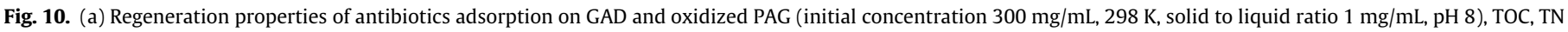
and COD removal rate of GAD, (b) under different time and, (c) under different GAD dosage, (d) TOC, TN and COD removal rate of GAD and oxidized PAG. 


\subsection{Effects of environmental factors}

Influence of $\mathrm{NaCl}$ concentration on antibiotic adsorption on GAD and PAG after physical and chemical modification is shown in Fig. 9a, from which it can be seen that the antibiotic adsorption capacity increases with the increase of $\mathrm{NaCl}$ concentration. This may due to the ion exchange between $\mathrm{Ca}^{2+}$ in the beads and $\mathrm{Na}^{+}$ in the solution helps the beads to open more channels to the pollutants. As $\mathrm{pH}$ could influence the charge type and functional groups of antibiotic, the study of the $\mathrm{pH}$ of on adsorption is shown in Fig. 9b. The adsorption capacity of the two antibiotics increased with the increase of $\mathrm{pH}$. In water, tetracycline would present four kinds of charge types with the $\mathrm{pH}$ increase, which are $\mathrm{H}_{3} \mathrm{TC}^{+}$ $(\mathrm{pH}<3.3), \mathrm{H}_{2} \mathrm{TC}^{0}(3.3<\mathrm{pH}<7.68), \mathrm{HTC}^{-}(7.68<\mathrm{pH}<9.68)$ and $\mathrm{TC}^{2-}(\mathrm{pH}<9.68)$ respectively [49]. Ciprofloxacin would present three kinds of charge types with the $\mathrm{pH}$ increase, which are $\mathrm{CIP}^{+}(-$ $\mathrm{pH}<6.1), \mathrm{CIP}^{0}(6.1<\mathrm{pH}<8.7)$ and $\mathrm{CIP}^{-}(\mathrm{pH}<8.7)[50]$ respectively. Therefore, both tetracycline and ciprofloxacin changed from the positively charged into negatively charged with $\mathrm{pH}$ increase, resulting in the change of electrostatic interaction between the antibiotic and the adsorbent from electrostatic attraction into electrostatic repulsion. Thus the adsorption capacity decreased at high $\mathrm{pH}$. Influence of $\mathrm{Cu}^{2+}$ on antibiotic adsorption is shown in Fig. 9c. In coexistence of $\mathrm{Cu}^{2+}$, the $\mathrm{Cu}^{2+}$ could promote the antibiotic adsorption under a certain concentration; however, while $\mathrm{Cu}^{2+}$ concentration is high the antibiotic adsorption capacity begins to decrease due to competitive adsorption. Under a lower $\mathrm{Cu}^{2+}$ concentration, the reason for the promotion effect is that $\mathrm{Cu}^{2+}$ could bind with carboxyl and hydroxyl groups in the adsorbent and amino groups in ciprofloxacin to act as a bridge [51]. As the PAG contains more carboxyl and hydroxyl groups than GAD, the promotion degree is more obvious for PAG than for GAD.

\subsection{Regeneration properties and the application of the real life wastewater}

Regeneration of antibiotics adsorption on GAD and oxidized PAG is shown in Fig. 10a. After 10 cycles, the adsorbents still has a high adsorption capacity for antibiotics, and the PAG showed higher reusability than the GAD. To evaluate the practical application in water treatment of the double network, domestic wastewater was used as water sample. After $24 \mathrm{~h}$, the removal rate of COD, $\mathrm{TN}$, and TOC in domestic sewage was $15.5 \%, 24.8 \%$ and $35.8 \%$, which reflects that the double network hydrogel had great application value in the actual sewage treatment. TOC, TN and COD removal rate of GAD under different time and different GAD dosage are shown in Fig. 10b and c. After $20 \mathrm{~h}$, the removal of the pollutants comes to equilibrium, and $1 \mathrm{mg} / \mathrm{mL}$ is selected as the best dosage. The removal rate of TOC, TN, and COD by GAD and oxidized PAG in real domestic wastewater is shown in Fig. 10d. GAD showed to have a certain effect on the removal of actual domestic wastewater, with the removal rate of $15.5 \%, 24.8 \%$ and $35.8 \%$ for TOC, TN, and COD respectively, while the oxidized PAG is better, which is $25.8 \%, 36.9 \%$ and $47.4 \%$ for TOC, TN and COD respectively. Among the existing mature technologies, Saeed et al. [52] used artificial wetland to treat sewage, and the removal rate of COD is about $80 \%$. Ueda et al. [53] used membrane biological reactor for domestic sewage treatment, and the removal rates of TOC and TN were 93 $\%$ and $79 \%$, respectively. Although the treatment efficiency of double network for domestic sewage is not as good as the mature technologies, it still has great potential.

\section{Conclusions}

To improve the adsorption capacity of double network hydrogel, physical and chemical modifications are made on alginate/graphene double network hydrogel. The modified hydrogel features a more porous structure and more functional groups than that before modification. In ciprofloxacin adsorption, the adsorption capacity increases with increasing GO content and initial $\mathrm{CaCO}_{3}$ content. Hydrogen bond contributes more than carboxyl group. The modifed hydrogel also leads to better removal rates for TOC, TN, and COD than the initial double network in sewage treatment. This investigation provide an effective way for double network hydrogel modification, which may have great value for the application of double network hydrogel in water treatment.

\section{Acknowledgment}

This research was supported by the National Natural Science Foundation of China (grant nos. 21577099 and 51408362), State Key Laboratory of Pollution Control and Resource Reuse Foundation (NO. PCRRIC16001), and the Natural Science Foundation of Jiangsu Province(Grants No BK20151300).

\section{Appendix A. Supplementary material}

Supplementary data associated with this article can be found, in the online version, at http://dx.doi.org/10.1016/j.jcis.2017.07.033.

\section{References}

[1] A. Abdolali, W.S. Guo, H.H. Ngo, S.S. Chen, N.C. Nguyen, K.L. Tung, Bioresource Technol. 160 (2014) 57.

[2] C.W. Knapp, J. Dolfing, P.A.I. Ehlert, D.W. Graham, Environ. Sci. Technol. 44 (2010) 580.

[3] A.J. Watkinson, E.J. Murby, S.D. Costanzo, Water res. 41 (2007) 4164.

[4] C.L. Amorim, I.S. Moreira, A.S. Maia, M.E. Tiritan, P.M. Castro, Appl. Microbiol. Biotechnol. 98 (2014) 3181.

[5] F.C. Moreira, S. Garcia-Segura, R.A.R. Boaventura, E. Brillas, V.J.P. Vilar, Appl. Catalysis B: Environ. 160-161 (2014) 492.

[6] P. Liu, H. Zhang, Y. Feng, F. Yang, J. Zhang, Chem. Eng. J. 240 (2014) 211.

[7] B.M. Souza, M.W.C. Dezotti, R.A.R. Boaventura, V.J.P. Vilar, Chem. Eng. J. 256 (2014) 448.

[8] F. Yu, Y. Li, S. Han, J. Ma, Chemosphere 153 (2016) 365.

[9] N. Le-Minh, S.J. Khan, J.E. Drewes, R.M. Stuetz, Water Res. 44 (2010) 4295.

[10] X.-R. Jing, Y.-Y. Wang, W.-J. Liu, Y.-K. Wang, H. Jiang, Chem. Eng. J. 248 (2014) 168.

[11] X. Qin, F. Liu, G. Wang, L. Li, Y. Wang, L. Weng, Chemosphere 111 (2014) 283.

[12] P. Trivedi, D. Vasudevan, Environ. Sci. Technol. 41 (2007) 3153.

[13] R. Figueroa, A. Mackay, Environ. Sci. Technol. 39 (2005) 6664.

[14] O. Lorphensri, J. Intravijit, D.A. Sabatini, T.C. Kibbey, K. Osathaphan, C. Saiwan, Water Res. 40 (2006) 1481.

[15] M. Anggraini, A. Kurniawan, L.K. Ong, M.A. Martin, J.-C. Liu, F.E. Soetaredjo, N. Indraswati, S. Ismadji, RSC Advances 4 (2014) 16298.

[16] Z. Li, H. Hong, L. Liao, C.J. Ackley, L.A. Schulz, R.A. MacDonald, A.L. Mihelich, S. M. Emard, Colloids and Surfaces B: Biointerfaces 88 (2011) 339.

[17] Z. Wang, X. Yu, B. Pan, B. Xing, Environ. sci. technol. 44 (2010) 978.

[18] Y. Gao, Y. Li, L. Zhang, H. Huang, J. Hu, S.M. Shah, X. Su, J. Colloid Interf. Sci. 368 (2012) 540.

[19] Y. Tang, H. Guo, L. Xiao, S. Yu, N. Gao, Y. Wang, Colloids and Surfaces A: Physicochemical and Eng. Aspects 424 (2013) 74.

[20] B. Zhang, H. Zhang, X. Li, X. Lei, C. Li, D. Yin, X. Fan, Q. Zhang, Mater. Sci. Eng. C, Mater. for Biol. Appl. 33 (2013) 4401.

[21] S. Fukahori, T. Fujiwara, J. Hazard. Mater. 272 (2014) 1.

[22] L. Shao, Z. Ren, G. Zhang, L. Chen, Mater. Chem. Phys. 135 (2012) 16.

[23] J. Ma, M.X. Yang, F. Yu, J. Zheng, Sci. Rep. 5 (2015).

[24] Y. Zhuang, F. Yu, J. Ma, J. Chen, Rsc Advances 5 (2015) 27964.

[25] Y. Zhuang, F. Yu, H. Chen, J. Zheng, J. Ma, J.H. Chen, J. Mater. Chem. A 4 (2016) 10885.

[26] Y. Zhuang, F. Yu, J. Chen, J. Ma, J. Environ. Chem. Eng. 4 (2016) 147.

[27] S. Partap, I. Rehman, J.R. Jones, J.A. Darr, Adv. Mater. 18 (2006) 501.

[28] L. Sun, B. Fugetsu, Chem. Eng. J. 240 (2014) 565.

[29] R.Z. Xie, W.J. Jiang, H. Wang, Y.X. Jiang, X. Huang, Y. Chen, Fresen. Environ. Bull. 23 (2014) 2388.

[30] M. Hirata, T. Gotou, S. Horiuchi, M. Fujiwara, M. Ohba, Carbon 42 (2004) 2929.

[31] S. Mao, H.H. Pu, J.H. Chen, RSC Advances 7 (2012) 2643.

[32] H.P. Boehm, Carbon 40 (2002) 145.

[33] Z. Wu, H. Zhong, X. Yuan, H. Wang, L. Wang, X. Chen, G. Zeng, Y. Wu, Water Res. 67 (2014) 330.

[34] F.A. Bertoni, A.C. Medeot, J.C. Gonzalez, L.F. Sala, S.E. Bellu, J. colloid interf. sci. 446 (2015) 122.

[35] D.K. Mahmoud, M.A.M. Salleh, W.A.W.A. Karim, A. Idris, Z.Z. Abidin, Chem. Eng. J. 181-182 (2012) 449. 
[36] L. Obeid, A. Bee, D. Talbot, S. Ben Jaafar, V. Dupuis, S. Abramson, V. Cabuil, M. Welschbillig, J. colloid interf. sci. 410 (2013) 52.

[37] W.H. Cheung, Y.S. Szeto, G. McKay, Bioresource Technol. 98 (2007) 2897.

[38] I.A. Tan, A.L. Ahmad, B.H. Hameed, J. Hazard. Mater. 154 (2008) 337.

39] M.A. Ahmad, R. Alrozi, Chem. Eng. J. 171 (2011) 510.

[40] E. Erdem, N. Karapinar, R. Donat, J. Colloid Interf. Sci. 280 (2004) 309.

[41] S.S. Tahir, N. Rauf, Chemosphere 63 (2006) 1842.

[42] Y. Lin, S. Xu, J. Li, Chem. Eng. J. 225 (2013) 679.

[43] Y. Chao, W. Zhu, B. Yan, Y. Lin, S. Xun, H. Ji, X. Wu, H. Li, Changri, J. Appl. Poly. Sci. 131 (2014) 40561

[44] P. Liu, W.J. Liu, H. Jiang, J.J. Chen, W.W. Li, H.Q. Yu, Bioresource Technol. 121 (2012) 235.

[45] L. Huang, M. Wang, C. Shi, J. Huang, B. Zhang, Desalination and Water Treat. 52 (2014) 2678.
[46] A. Idris, N.A.M. Zain, M.S. Suhaimi, Process Biochem. 43 (2008) 331.

[47] B. Manjula, K. Varaprasad, R. Sadiku, K.M. Raju, Adv. Polym. Technol. 32 (2013) 21340.

[48] Y. He, N. Zhang, Q. Gong, H. Qiu, W. Wang, Y. Liu, J. Gao, Carbohyd. Polym. 88 (2012) 1100.

[49] Y. Zhao, F. Tong, X. Gu, C. Gu, X. Wang, Y. Zhang, Sci. Total. Environ. 470-471 (2014) 19

[50] C. Gu, K.G. Karthikeyan, Environ. Sci. Technol. 39 (2005) 9166.

[51] Y. Zhuang, F. Yu, J. Ma, J. Chen, New J. Chem. 39 (2015) 3333.

[52] T. Saeed, R. Afrin, A. Al Muyeed, G. Sun, Chemosphere 88 (2012) 1065.

[53] T. Ueda, K. Hata, Water Res. 33 (1999) 2888. 